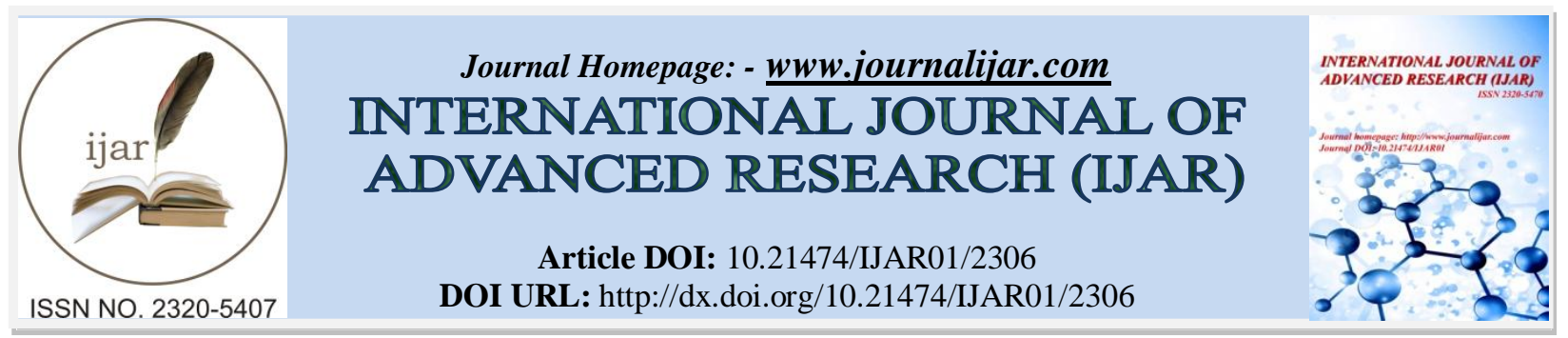

RESEARCH ARTICLE

\title{
EVALUATION OF MUTATION OF TP53 GENE WITH RISK OF SQUAMOUS CELL CARCINOMA HEAD AND NECK (HNSCC) IN KASHMIRI POPULATION.
}

\author{
Dr Shakeel Mohmad Wani ${ }^{1}$, Dr Asif Mahajan ${ }^{2}$, Dr Zubair Ahmad Lone ${ }^{1}$, Dr Shahnaz Sheikh ${ }^{1}$, Dr Rafiq \\ Ahmad Pampori ${ }^{3}$ and Dr Sabia Majid ${ }^{4}$. \\ 1. Resident ENT HNS, SMHS Hospital, Srinagar, Kashmir, India. \\ 2. Resident ENT, SKIMS Medical College, Srinagar, Kashmir, India. \\ 3. Ex-Principal Government Medical College Srinagar, Kashmir, India. \\ 4. Head of Department, Biochemistry, Government Medical College, Srinagar, Kashmir, India.
}

\section{Manuscript Info}

Manuscript History

Received: 29 September 2016

Final Accepted: 30 October 2016

Published: November 2016

Key words:-

Squamous cell carcinoma Head and neck, Tp53 mutation,

Immunohistochemistry.

\section{Abstract}

Objective:- To find relationship between TP53 mutations and squamous cell carcinoma head and neck (SCCHN) .

Study design: Case control study.

Setting: Tertiary care hospital (SMHS associated Medical College, Srinagar, Kashmir, India)

Participants: 50 cases and 50 controls of squamous cell carcinoma head and neck reported our hospital from 2013-2016.

Conclusion: In the present study, HNSCC patients showed 15(30\%) GG (Arginine/Arginine), 26(52\%) GC (Arginine/Proline) and 9 (18\%) CC (Proline/Proline) genotypes and controls shows 31(62\%) GG, $11(22 \%) \mathrm{GC}$ and $8(16 \%)$ CC. It was observed that TP53 codon 72 polymorphism was significantly associated with HNSCC. The frequency of homozygous CC (Proline/Proline) genotype was elevated in HNSCC cases compared to controls $(\mathrm{P}<0.0003, \mathrm{RR} 1.845,95 \%$ CI 1.264-2.693, OR 3.845), where as frequency of Arg/Arg ( $\mathrm{P}$ Value $=$ $0.0024, \mathrm{RR} 0.563,95 \%$ CI $0.3177-0.7967, \mathrm{OR}$. 0.2627) were elevated in controls compared to cases.

Copy Right, IJAR, 2016,. All rights reserved.

\section{Background:-}

P53 was identified in 1979 by Lionel Crawford, David P. Lane, Arnold Levine, and Lloyd Old, working at Imperial Cancer Research Fund (UK) Princeton University/UMDNJ (Cancer Institute of New Jersey), and Memorial SloanKettering Cancer Center, respectively. It had been hypothesized to exist before as the target of the SV40 virus, a strain that induced development of tumors. The TP53 gene from the mouse was first cloned by Peter Chumakov of the Russian Academy of Sciences in $1982^{1}$ and independently in 1983 by Moshe Oren in collaboration with David Givol (Weizmann Institute of Science). ${ }^{2,3}$ The human TP53 gene was cloned in 1984 and the full length clone in $1985^{4}$

In humans, the TP53 gene is located on the short arm of chromosome $17(17 \mathrm{p} 13.1)^{5,6,7,8}$ the gene spans $20 \mathrm{~kb}$, with a non-coding exon 1 and a very long first intron of $10 \mathrm{~kb}$. The coding sequence contains five regions showing a high degree of conservation in vertebrates, predominantly in exons $2,5,6,7$ and 8 , but the sequences found in 
invertebrates show only distant resemblance to mammalian TP53TP53orthologs have been identified in most mammals for which complete genome data are available.

In humans, a common polymorphism involves the substitution of an arginine for a proline at codon position 72 . Many studies have investigated a genetic link between this variation and cancer susceptibility; however, the results have been controversial. For instance, a meta-analysis from 2009 failed to show a link for cervical cancer ${ }^{9}$. A 2011 study found that the TP53 proline mutation did have a profound effect on pancreatic cancer risk among males. ${ }^{10} \mathrm{~A}$ study of Arab women found that proline homozygosity at TP53 codon 72 is associated with a decreased risk for breast cancer. ${ }^{11}$

Meta-analyses from 2011 found no significant associations between TP53 codon 72 polymorphisms and both colorectal cancer risk ${ }^{12}$ and endometrial cancer risk. ${ }^{13}$ A 2011 study of a Brazilian birth cohort found an association between the non mutant arginine TP53 and individuals without a family history of cancer. ${ }^{14}$ Another 2011 study found that the p53 homozygous (Pro/Pro) genotype was associated with a significantly increased risk for renal cell carcinoma. ${ }^{15}$

The TP53 gene can also be modified by mutagens (chemicals, radiation, or viruses), increasing the likelihood for uncontrolled cell division. More than 50 percent of human tumors contain a mutation or deletion of the TP53 gene. ${ }^{16}$ Loss of p53 creates genomic instability that most often results in an aneuploidy phenotype. ${ }^{17}$

Increasing the amount of p53 may seem a solution for treatment of tumors or prevention of their spreading. This, however, is not a usable method of treatment, since it can cause premature aging. ${ }^{18}$ Restoring endogenous normal p53 function holds some promise. Research has shown that this restoration can lead to regression of certain cancer cells without damaging other cells in the process. The ways by which tumor regression occurs depends mainly on the tumor type. For example, restoration of endogenous p53 function in lymphomas may induce apoptosis, while cell growth may be reduced to normal levels. Thus, pharmacological reactivation of p53 presents itself as a viable cancer treatment option. ${ }^{1920}$ The first commercial gene therapy, Gendicine, was approved in China in 2003 for the treatment of head and neck squamous cell carcinoma. It delivers a functional copy of the p53 gene using an engineered adenovirus. ${ }^{21}$

\section{Aim of the study:-}

* To find relationship between TP53 mutations and squamous cell carcinoma head and neck (SCCHN.

\section{Materials and methods:-}

\section{Study subjects:-}

- This study was done in tertiary health centre of kashmir in Department of ENT and Head \& Neck surgery SMHS and included patients with histologically confirmed squamous cell carcinoma Head and neck (SCCHN )over a period of 18 months. Patients with squamous cell carcinoma of oral cavity, oropharynx, nasal cavity, nasopharynx, hypopharynx and larynx, identified at the Department of ENT and head\&neck surgery SMHS Hospital were included. The patients with secondary SCCHN, Thyriod malignancies, primaries outside the upper aero digestive tract, cervical metastases of unknown origin or histopathologic diagnoses other than squamous cell carcinoma were excluded. All cases were from Kashmir and had not received any treatment at the time of recruitment. Controls were also taken from Kahmiri population who were admitted to our hospital for some other non-neoplastic disease. After verbal and written consent $2 \mathrm{ml}$ of blood sample was taken from controls and analysed for genetic mutation .

- From Histologically proven patients of squamous cell carcinoma. $2 \mathrm{ml}$ of blood was taken from each patient after proper consent and was analysed at the Department of Biochemistry (DNA extraction and genotyping). Samples were stored at temperature $-80^{\circ} \mathrm{c}$.

\section{Genotyping:-}

From each blood sample of case and control, a leukocyte cell pellet was obtained from the buffy coat by centrifugation of $2 \mathrm{ml}$ of whole blood for DNA extraction. Genomic DNA was isolated with the help of DNA extraction kit (Biotools Spain). 
After the isolation of DNA from the samples, Polymerase Chain Reaction (PCR) using Thermal cycler (Eppendorf) was performed to amplify TP53 genes to see whether there is any mutation in this gene using specificprimers Listed in table1.

Table 1:- Shows Forward and Reverse Primers for TP53 Gene Used For Polymerase Chain Reaction of the above three different genes in Head \& Neck Carcinoma cases and controls

\begin{tabular}{|l|l|l|}
\hline Gene & Forward primer & Reverse primer \\
\hline & 5'- ATCTACAGTCCCCCTTGCCG-3' $^{\prime}$ & 5'-GCAACTGACCGTGCAAGTCA-3' $^{\prime}$ \\
\hline
\end{tabular}

The reaction volume was $25 \mu \mathrm{L}$ containing the reagents listed in table 2 and the PCR conditions for the above three genes are listed in table 3 below

Table 2:- Shows Reagents Used For Polymerase Chain Reaction of the above three different genes in Head \& Neck Carcinoma cases and controls

\begin{tabular}{|l|l|}
\hline Reagents & TP53 gene \\
\hline Modified DNA & $2 \mu \mathrm{l}$ \\
\hline dNTPs & $1 \mu \mathrm{l}$ \\
\hline Forward \& Reverse Primer & $1.5 \mu \mathrm{l}$ each \\
\hline Taq Buffer & $2 \mu \mathrm{l}$ \\
\hline DMSO & $3 \mu \mathrm{l}$ \\
\hline Taq DNA Polymerase & $0.2 \mu \mathrm{l}(5 \mathrm{U} / \mu \mathrm{l})$ \\
\hline Deionised Water & $15.3 \mu \mathrm{l}$ \\
\hline Total Volume & $25 \mu \mathrm{l}$ \\
\hline
\end{tabular}

Table 3:-

\begin{tabular}{|l|l|l|}
\hline Condition & TP53 gene & \\
\hline Initial Denaturation & $96^{\circ} \mathrm{C}, 5 \mathrm{~min}$ & \multirow{3}{*}{35 cycles } \\
\hline Denaturation & $96^{\circ} \mathrm{C}, 45 \mathrm{sec}$ & \\
\hline Annealing & $56^{\circ} \mathrm{C}, 45 \mathrm{sec}$ & \\
\hline Extension & $72^{\circ} \mathrm{C}, 30 \mathrm{sec}$ & \\
\hline Final elongation & $72^{\circ} \mathrm{C}, 5 \mathrm{~min}$ & \\
\hline
\end{tabular}

After the PCR was over, $10 \mu \mathrm{L}$ of the PCR products were run on $2.5 \%$ agarose gel using electrophoresis apparatus and PCR products were verified 296bp for Tp53 gene .

For analysing TP53 (Arg72Pro) polymorphism the PCR product was digested by MspI (Biotools Spain) overnight at $37^{\circ} \mathrm{C}$. The digested product was separated on $2.5 \%$ agarose gel with ethidium bromide and was photographed with the help of gel documentation system present in Biochemistry lab. The wild-type allele (GG) produced two bands (169 and $127 \mathrm{bp}$ ); wild-type/variant allele (GC) produced 169, 127 and $296 \mathrm{bp}$ and the variant allele (CC) which lacks the MspI restrictionsite produced a single $296 \mathrm{bp}$ band.

\section{Results and observations:-}

This study was taken to understand the affect of TP53 gene polymorphism in Head \& Neck squamous cell Carcinoma patients. Genomic DNA was isolated from all Samples by using kit provided by Zymo-Research.

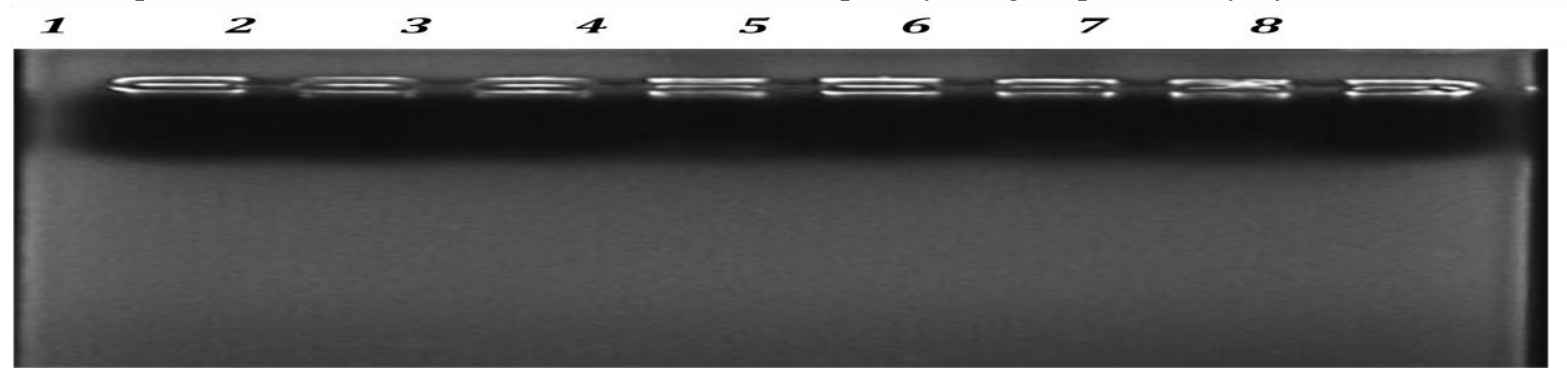

Figure 1:- Representative gel picture run on $0.8 \%$ agarose showing isolated Genomic DNA L1-L5= Cases of Head \& Neck carcinoma,L6-L8= Controls. 
. Negative control with ddH2O instead of DNA template was included in each PCR run. Statistical analysis was performed using fishers exact test.

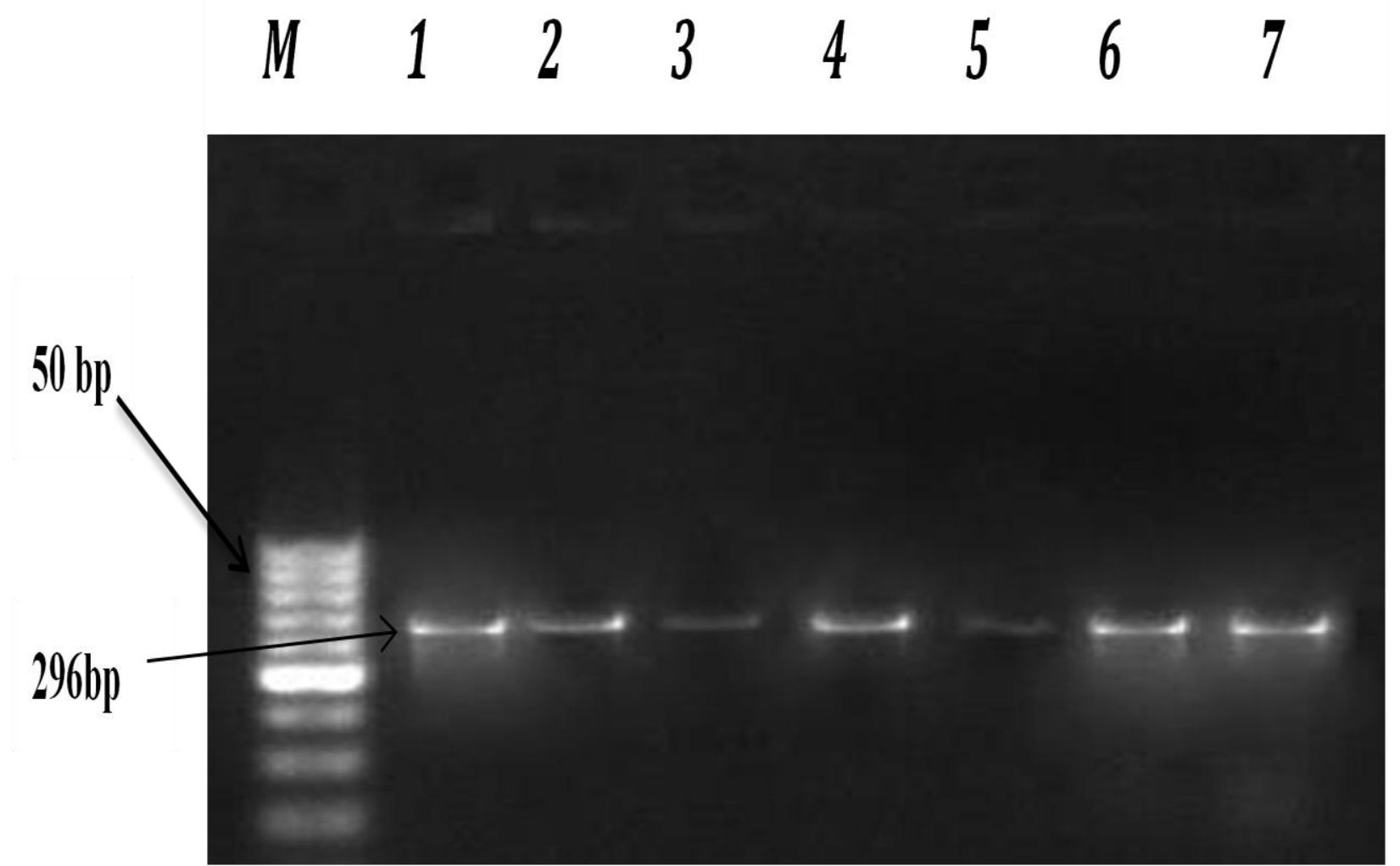

Figure 4:- PCR amplification of TP53 (Arg 72 pro) gene showing band size of 296bp LM=50bp Molecular Marker DNA ladder .

L1-L7=Cases of Head \& Neck Carcinoma

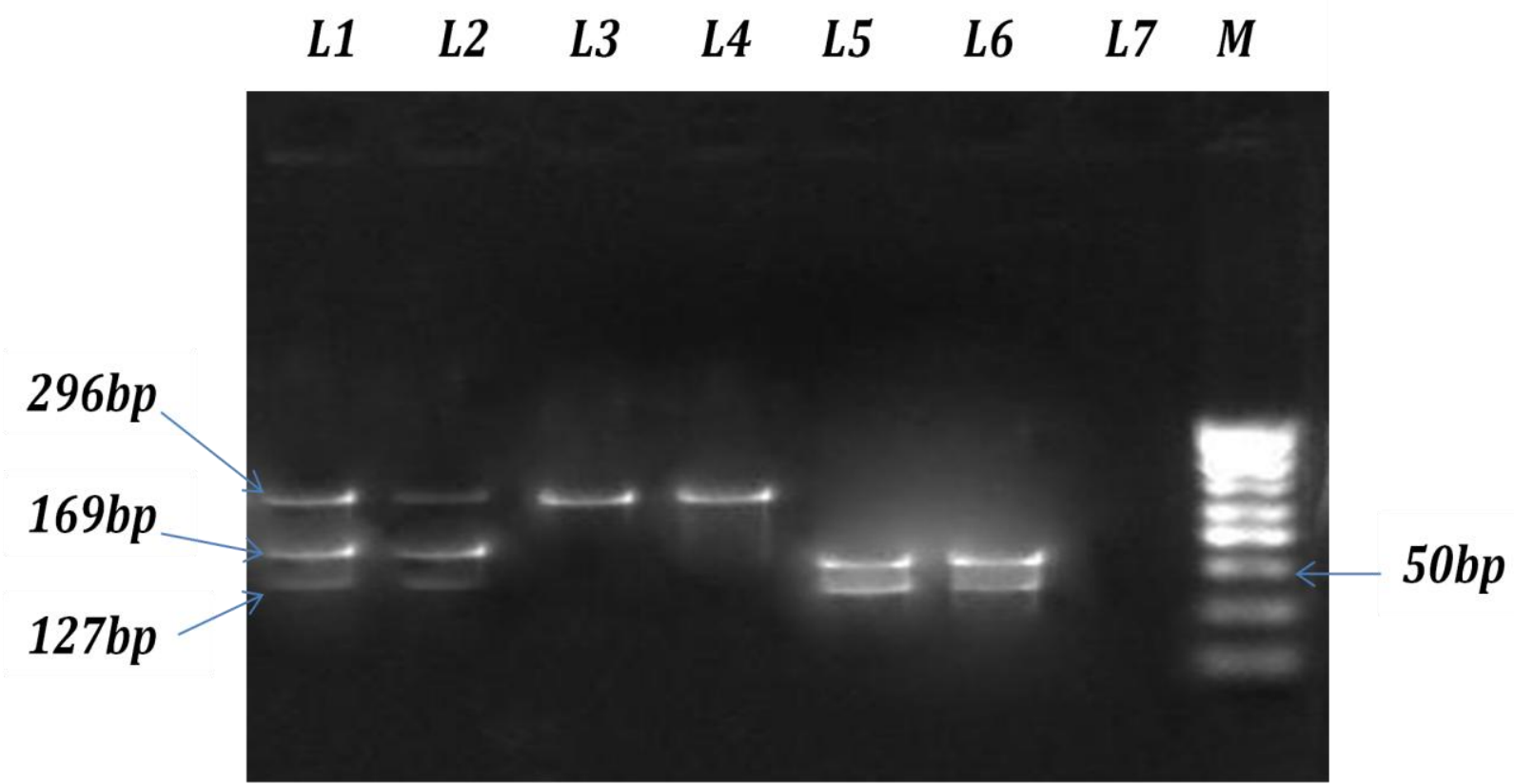

Figure 7:- BstUI Restriction digestion of PCR product with TP53 (Arg72 Pro) polymorphic sites L1,L2= Heterozygous GA genotype (169bp, 127bp \& 296bp)

L3, L4=Homozygous AA genotype (296bp) 
L5, L6=Homozygous AA genotype (169bp \& 127bp )

L7=Negative Control (water) and

$\mathrm{LM}=$ Molecular Marker 50bp DNA Ladder

\section{Results:-}

In the present study, HNSCC patients showed 15(30\%) GG (Arginine/Arginine), 26(52\%) GC (Arginine/Proline) and 9 (18\%) CC (Proline/Proline) genotypes and controls shows 31(62\%) GG, 11(22\%) GC and 8(16\%) CC. It was observed that codon 72 polymorphism was significantly associated with HNSCC. The frequency of homozygous CC (Proline/Proline) genotype was elevated in HNSCC cases compared to controls ( $\mathrm{P}<0.0003, \mathrm{RR} 1.845,95 \%$ CI 1.2642.693,OR 3.845), where as frequency of Arg/Arg (P Value $=0.0024, \mathrm{RR} 0.563,95 \%$ CI $0.3177-0.7967, \mathrm{OR} .0 .2627$ ) were elevated in controls compared to cases (Table 5).

Table 5:- Frequency of TP53 gene genotypes.

\begin{tabular}{|l|l|l|l|l|}
\hline \multicolumn{2}{|c|}{ Results } \\
\hline & $\begin{array}{l}\text { Wild type GG } \\
\text { (Arg/Arg }\end{array}$ & $\begin{array}{l}\text { Homozygous CC } \\
\text { (Pro/Pro) }\end{array}$ & $\begin{array}{l}\text { Heterozygous GC } \\
\text { (Arg/Pro) }\end{array}$ & Row Totals \\
\hline CASES & 15 & 26 & 9 & 50 \\
\hline CONTROLS & 31 & 11 & 8 & 50 \\
\hline Column Totals & 46 & 37 & 17 & $\begin{array}{l}100 \text { (Grand } \\
\text { Total) }\end{array}$ \\
\hline
\end{tabular}

Data was analysed using Graph-pad prism softwear version-6 and the association was found statistically significant inrelation to TP53 gene as P Value $<0.05(0.002), \mathrm{RR}=1.988$, Odds ratio $=3.807$ and $95 \% \mathrm{CI}=1.255$ to 3.148

\section{Conclusion:-}

TP53 mutation has got definite association with head and neck squamous cell carcinoma in Kashmiri population with special reference to Laryngeal squamous cell carcinoma.

Most of the mutations of Tp53 has been found in aggressive tumours, advanced stage of disease so there is need to screen the population at risk early to prevent dreadful morbidity and mortality associated with disease.

Non-invasive simple blood based detection of TP53 mutation may serve as good screening tool The presence of TP53 mutation in these tumours represents a potential Tumour specific targeting opportunity for the development of new therapeutics

Ethical Clearance:- Sought from ethical committee GMC Srinagar.

Conflict of interest:- Nil

Source of funding:- Hospital

\section{Acknowledgement:-}

Nil

\section{Bibliography:-}

1. Chumakov PM, Iotsova VS, Georgiev GP (1982). "[Isolation of a plasmid clone containing the mRNA sequence for mouse nonviral T-antigen]". Dokl.Akad. Nauk SSSR (in Russian) 267 (5): 1272-5.

2. Oren M, Levine AJ (1983). "Molecular cloning of a cDNA specific for the murine p53 cellular tumor antigen". Proc. Natl. Acad. Sci. U.S.A. 80 (1): 56-9.

3. Zakut-Houri R, Oren M, Bienz B, Lavie V, Hazum S, Givol D (1983). "A single gene and a pseudogene for the cellular tumour antigen p53". Nature 306 (5943): 594-7.

4. Zakut-Houri R, Bienz-Tadmor B, Givol D, Oren M (1985). "Human p53 cellular tumor antigen: cDNA sequence and expression in COS cells". EMBO J. 4 (5): 1251-5.

5. Matlashewski G, Lamb P, Pim D, Peacock J, Crawford L, Benchimol S (1984). "Isolation and characterization of a human p53 cDNA clone: expression of the human p53 gene". EMBO J. 3 (13): 3257-62.

6. Isobe M, Emanuel BS, Givol D, Oren M, Croce CM (1986). "Localization of gene for human p53 tumour antigen to band 17p13". Nature 320 (6057): 84-5. 
7. Kern SE, Kinzler KW, Bruskin A, Jarosz D, Friedman P, Prives C, Vogelstein B (1991). "Identification of p53 as a sequence-specific DNA-binding protein". Science 252 (5013): 1708-11.

8. McBride OW, Merry D, Givol D (1986)."The gene for human p53 cellular tumor antigen is located on chromosome 17 short arm (17p13)". Proc. Natl. Acad. Sci. U.S.A. 83 (1): 130-134.

9. Klug SJ, Ressing M, Koenig J, Abba MC, Agoras VM, Sengupta S, Settheetham-Ishida W, Shirasawa H, Snijders PJ, Stoler MH, Suárez-Rincón AE, Szarka K, Tachezy R, Ueda M, van der Zee AG, von Knebel Doeberitz M, Wu MT, Yamashita T, Zehbe I, Blettner M (2009). "TP53 codon 72 polymorphism and cervical cancer: a pooled analysis of individual data from 49 studies". Lancet Oncology 10 (2): 772-784.

10. Sonoyama T, Sakai A, Mita Y, Yasuda Y, Kawamoto H, Yagi T, Yoshioka M, Mimura T, Nakachi K, Ouchida M, Yamamoto K, Shimizu K (2011). "TP53 codon 72 polymorphism is associated with pancreatic cancer risk in males, smokers and drinkers". Mol Med Report 4 (3): 489-95.

11. Alawadi S, Ghabreau L, Alsaleh M, Abdulaziz Z, Rafeek M, Akil N, Alkhalaf M (2011). "P53 gene polymorphisms and breast cancer risk in Arab women". Med. Oncol. 28 (3): 709-15.

12. Wang JJ, Zheng Y, Sun L, Wang L, Yu PB, Dong JH, Zhang L, Xu J, Shi W, Ren YC (2011). "TP53 codon 72 polymorphism and colorectal cancer susceptibility: a meta-analysis". Mol. Biol. Rep. 38 (8): 4847-53.

13. Jiang DK, Yao L, Ren WH, Wang WZ, Peng B, Yu L (2011). "TP53 Arg72Pro polymorphism and endometrial cancer risk: a meta-analysis". Med. Oncol. 28 (4): 1129-35

14. Thurow HS, Haack R, Hartwig FP, Oliveira IO, Dellagostin OA, Gigante DP, Horta BL, Collares T, Seixas FK (2011). "TP53 gene polymorphism: importance to cancer, ethnicity and birth weight in a Brazilian cohort". J. Biosci. 36 (5): 823-31.

15. Huang CY, Su CT, Chu JS, Huang SP, Pu YS, Yang HY, Chung CJ, Wu CC, Hsueh YM (2011). "The polymorphisms of P53 codon 72 and MDM2 SNP309 and renal cell carcinoma risk in a low arsenic exposure area". Toxicol. Appl. Pharmacol. 257 (3): 349-55.

16. Hollstein M, Sidransky D, Vogelstein B, Harris CC (1991). "p53 mutations in human cancers". Science 253 (5015): 49-53.

17. Schmitt CA, Fridman JS, Yang M, Baranov E, Hoffman RM, Lowe SW (2002). "Dissecting p53 tumor suppressor functions in vivo". Cancer Cell 1 (3): 289-298.

18. Tyner SD, Venkatachalam S, Choi J, Jones S, Ghebranious N, Igelmann H, Lu X, Soron G, Cooper B, Brayton C, Hee Park S, Thompson T, Karsenty G, Bradley A, Donehower LA (2002). "p53 mutant mice that display early ageing-associated phenotypes". Nature 415 (6867): 45-53.

19. Ventura A, Kirsch DG, McLaughlin ME, Tuveson DA, Grimm J, Lintault L, Newman J, Reczek EE, Weissleder R, Jacks T (2007). "Restoration of p53 function leads to tumour regression in vivo". Nature 445 (7128): 661-5.

20. Herce HD, Deng W, Helma J, Leonhardt H, Cardoso MC (2013). "Visualization and targeted disruption of protein interactions in living cells". Nat Commun 4: 2660.

21. Pearson S, Jia H, Kandachi K (Jan 2004). "China approves first gene therapy". Nature Biotechnology 22 (1): 3 4. 